ks. Jan Dyduch

\title{
Godność kobiety w Kościele
}

Współcześnie jesteśmy świadkami szerzenia się różnego rodzaju feminizmów. Bardzo często ukazują one godność kobiety w sposób niewłaściwy, propagując np. ideologię gender czy głosząc, że wolność kobiety polega na tym, iż może zadecydować o zabiciu jeszcze nienarodzonego dziecka. Są to fałszywe feminizmy, poniżające i degradujące kobiety. W tej sytuacji trzeba głosić i bronić godności kobiety.

W niniejszym artykule zamierzamy, przynajmniej w ogólnym zarysie, przedstawić godność kobiety i jej rolę w Kościele. Tę prezentację chcemy oprzeć głównie na Piśmie Świętym, na nauczaniu Vaticanum II, na liście apostolskim Mulieris dignitatem ${ }^{1}$ oraz innych dokumentach Urzędu Nauczycielskiego Kościoła.

\section{Podstawy nauczania o godności kobiety}

Podstawy nauczania o godności kobiety znajdujemy już na pierwszych kartach Pisma Świętego. Głosi ono, że człowiek został stworzony na obraz i podobieństwo Boga: „Stworzył Bóg człowieka, na swój obraz, na obraz Boży go stworzył, stworzył mężczyznę i kobietę" (Rdz 1, 27). To krótkie stwierdzenie wyraźnie wskazuje na fakt, że w godności ludzkiej mężczyzna i kobieta są sobie równi. Mężczyzna i kobieta są pełnoprawnymi istotami ludzkimi, mimo

1 Jan Paweł II, list apost. Mulieris dignitatem o godności i powołaniu kobiety, Częstochowa 2001 [dalej: MD]. 
iż istnieją między nimi wielorakie różnice, które w niczym nie naruszają ich godności ludzkiej. Naucza Jan Paweł II: „[...] człowiek jest szczytem całego porządku stworzenia w świecie widzialnym; rodzaj ludzki, który bierze początek w powołaniu do istnienia mężczyzny i kobiety, wieńczy całe dzieło stworzenia; istotami ludzkimi są oboje, w równym stopniu mężczyzna i kobieta, oboje stworzeni na obraz Boga”.

Z woli Boga Stwórcy ten istotny obraz - podobieństwo Boże - mężczyzny i kobiety zostaje przekazany wszystkim ludziom, wszystkim mężczyznom i kobietom. Dzięki temu Stwórca powierza wszystkim mężczyznom i kobietom panowanie nad ziemią. Upoważnia ich do tego fakt, że są osobami, czyli jedynymi istotami wśród stworzeń świata widzialnego, których Bóg chciał dla nich samych³. „Obraz i podobieństwo Boże w człowieku sprawia, że jest osobą: Człowiek jest osobą, w równej mierze mężczyzna i kobieta, oboje wszakże zostali stworzeni na obraz i podobieństwo Boga osobowego" 4 . Im więcej wiemy o Bogu, tym więcej wiemy o człowieku. Wiele prawd o Bogu objawił nam Jezus Chrystus w swojej Ewangelii, w swoim życiu i nauczaniu. Objawiając Trójcę Świętą, Jezus rzuca nowe światło na prawdę o obrazie Boga w człowieku:

To, że człowiek stworzony jako mężczyzna i kobieta jest obrazem Boga, znaczy nie tylko, iż każdy z nich z osobna jest podobny do Boga, będąc istotą rozumną i wolną. Znaczy to również, że mężczyzna i kobieta stworzeni jako „jedność dwojga” we wspólnym człowieczeństwie, są wezwani do życia we wspólnocie miłości i do

\footnotetext{
2 MD 6.

3 Por. GS 24.

4 MD 6.
} 
odzwierciedlenia w ten sposób w świecie tej komunii i miłości, jaka jest w Bogu, komunii poprzez którą Osoby Boskie miłują się w wewnętrznej tajemnicy jednego życia Bożego5.

Obraz Boga w człowieku sprawia, że jest on istotą rozumną i wolną. Rozum i wolna wola to fundament godności człowieka, który jest osobą; dotyczy to zarówno mężczyzny, jak i kobiety. Rozumność i wolność ujawniają w nich obraz Boga oraz uzdalniają ich do panowania nad innymi stworzeniami. To panowanie realizuje człowiek przez działanie rozumne i wolne, tylko w takim działaniu jawi się godność człowieka. Wolność to szczególny przejaw obrazu Bożego w człowieku:

Prawdziwa zaś wolność to wzniosły znak obrazu Boga w człowieku. Bóg bowiem chciał dać człowiekowi możliwość rozstrzygania o własnym losie, tak aby z własnej woli szukał swojego Stworzyciela i trwając przy nim w wolności, osiągał pełną i błogosławioną doskonałość. Godność człowieka wymaga więc, aby działał według świadomego i wolnego wyboru... ${ }^{6}$.

Wolność działania człowieka zakłada jego rozumność, tzn. zdolność do poznania prawdy. Wolność nie polega na swobodzie czynienia czegokolwiek, ale na czynieniu dobra, które człowiek poznaje swoim rozumem. Poznana prawda ma kierować jego wolą, dzięki temu człowiek staje się wolny7. O powiązaniu prawdy i wolności naucza Jan Paweł II: „Blask prawdy jaśnieje we wszystkich dziełach Stwórcy [...] prawda oświeca rozum i kształtuje wolność człowieka”.

$5 \quad$ MD 7.

6 Sobór Watykański II, konst. Gaudium et spes [dalej: KDK], 17.

7 Por. Kongregacja Doktryny Wiary, instr. Libertatis conscientia, 26.

8 Jan Paweł II, enc. Veritatis splendor, wstęp. 
Człowiek - osoba rozumna i wolna - jest powołany, aby bytować dla drugiego, aby składać bezinteresowny dar z siebie: „W jedności obojga mężczyzna i kobieta są od początku wezwani nie tylko do tego, aby bytować obok siebie czy nawet razem ze sobą, ale też wezwani do tego, aby bytować wzajemnie jedno dla drugiego"9. Konsekwencją tego, że człowiek jest stworzony na obraz i podobieństwo Boże, że jest wezwany, aby bytować dla drugich i stawać się darem, jest to, iż jest powołany do miłości, ma miłować i być miłowany. Chodzi tu o miłość, która jest z Boga i udziela się stworzeniu: „miłość Boża rozlana jest w sercach naszych przez Ducha Świętego, który został nam dany" (Rz 5, 5) ${ }^{10}$. W tym porządku miłości między osobami ludzkimi prym wiedzie kobieta, co dodaje blasku jej godności" ${ }^{11}$.

Człowiek stworzony przez Boga na jego obraz i podobieństwo, obdarowany darami przyrodzonymi i nadprzyrodzonymi, pod wpływem pokusy szatana popełnił grzech zwany pierworodnym. Człowiek - mężczyzna i kobieta - został dotknięty złem tego grzechu także w ten sposób, że obraz Boga zostaje w nim przyćmiony i pomniejszony, lecz nie wymazany. W konsekwencji również relacja między mężczyzną i kobietą, odpowiadająca osobowej godności każdego z nich, została zakłócona. Skutkiem grzechu pierworodnego jest także zachwianie i załamanie podstawowej równości, jaka istniała w ,jedności dwojga”, i to na niekorzyść kobiety. Ten stan został naprawiony poprzez zbawcze dzieło Jezusa Chrystusa' ${ }^{12}$.

Orędzie biblijne i ewangeliczne, głosząc prawdę o jednakowej godności ludzkiej mężczyzny i kobiety, strzeże tej godności.

\footnotetext{
$9 \quad \mathrm{MD} 7$.

$10 \quad \mathrm{MD} 29$.

11 Por. MD 29.

12 Por. MD 10.
} 
Podkreśla także odmienność i oryginalność osobową mężczyzny i kobiety:

Osobowe zasoby kobiecości na pewno nie są mniejsze od zasobów męskości. Są tylko inne. Kobieta więc - podobnie zresztą jak mężczyzna - musi pojmować swe osobowe spełnienie, swoją godność i powołanie w oparciu o te zasoby, według tego bogactwa kobiecości, jakie otrzymała w dniu stworzenia i które dziedziczy jako sobie właściwy wyraz obrazu i podobieństwa Bożego ${ }^{13}$.

Bogactwo kobiecości jest szczególną wartością kobiety, które ją charakteryzuje i rzutuje na jej godność' ${ }^{14}$.

W osobie Jezusa Chrystusa i w Jego posłannictwie jawi się w nowym świetle godność człowieka, a szczególnie godność kobiety. Chrystus zna godność człowieka i jej wartość w oczach Boga, gdyż On sam w dziele odkupienia staje się ostatecznym potwierdzeniem tej ceny. Chrystus, żyjąc w czasach dyskryminacji kobiet, staje w ich obronie. Stąd jest On rzecznikiem i obrońcą godności kobiety po wsze czasy'5. Wykazuje to Jan Paweł II, przeprowadzając analizę odniesienia Chrystusa do spotkanych kobiet, takich jak niewiasta samarytańska, niewiasta schwytana na cudzołóstwie, siostry Łazarza i kobiety - pierwsi świadkowie zmartwychwstania ${ }^{16}$.

Ewangelia głosi prawdę o godności człowieka, równości obojga - mężczyzny i kobiety, która nie niweczy ich różnorodności, odmienności i oryginalności: „Ewangeliczna równość i równouprawnienie kobiety i mężczyzny wobec wielkich spraw Bożych,

13 Por. MD 10.

14 Por. MD 29.

15 Por. J. Dyduch, Rola i zadania kobiet w Kościele i świecie w pracach VII Synodu Biskupów, „Roczniki Teologiczno-Kanoniczne” 36-37 (1989-1990), z. 5, s. 10.

16 MD 12-16. 
która tak przejrzyście uwydatniła się w czynach i słowach Jezusa z Nazaretu, stanowi bardziej oczywistą podstawę godności i powołania kobiety w Kościele i w świecie" ${ }^{17}$. Ukoronowaniem godności i powołania kobiety jest Najświętsza Maryja Panna, Matka i Dziewica, jaśniejąca na horyzoncie Kościoła i świata.

\section{Powołanie kobiety}

Najdoskonalszym wzorem godności i powołania człowieka, a przede wszystkim kobiety, jest Matka Boża. Naucza Sobór Watykański II: „Maryja, dzięki łasce Bożej wywyższona po Synu ponad wszystkich aniołów i ludzi, jako Najświętsza Matka Boża, która uczestniczyła w misteriach Chrystusa, słusznie doznaje od Kościoła szczególnej czci”ㄹ. Jezus Chrystus - Bóg Człowiek - objawia człowiekowi prawdę o Bogu i człowieku, dokonując dzieła odkupienia i zbawienia, ukazuje człowiekowi drogę powołania i zbawienia. W tym dziele szczególną rolę odgrywa Najświętsza Maryja Panna. Ona uczestniczy w centralnym wydarzeniu zbawczym, które urzeczywistnia się w Niej i przez Nią¹9. Maryja jako reprezentantka człowieczeństwa staje się Matką Boga, zaś pełnia łaski, która zostaje jej udzielona właśnie z tego powodu, oznacza zarazem pełnię doskonałości tego, co kobiece. Niewiasta - Bogarodzica jest rzeczywistością, która wyznacza istotny horyzont rozważania o godności i powołaniu kobiety, bowiem ostateczną ich miarą jest zjednoczenie z Bogiem. Dlatego Maryja jest najpełniejszym wyrazem tej godności i powołania. Bogarodzica Dziewica-Matka w niezwykły i cudowny sposób łączy w swej osobie dwa podstawowe wymiary powołania kobiety, macierzyństwo i dziewictwo, które

17 MD 16.

18 Sobór Watykański II, konst. Lumen gentium [dalej: KK], 66.

19 Por. MD 2-3. 
w niej współistnieją. W Maryi spotkały się one i zespoliły w sposób wyjątkowy, tak, iż jedno nie wykluczyło drugiego, ale przedziwnie je dopełniło ${ }^{20}$.

Macierzyństwo i dziewictwo to dwa szczególne wymiary spełnienia się kobiecej osobowości, to dwa wymiary kobiecego powołania. W normalnym biegu rzeczy macierzyństwo jest owocem zjednoczenia małżeńskiego mężczyzny i kobiety ${ }^{21}$. Trzeba podkreślić, w kontekście różnych błędnych i fałszywych ideologii, iż za małżeństwo uznajemy tylko i wyłącznie związek mężczyzny i kobiety. Każde małżeństwo ważnie zawarte ma charakter religijny i nie może być traktowane jako instytucja czysto świecka ${ }^{22}$. Szczególnie religijny i sakralny charakter ma ważnie zawarte małżeństwo między ochrzczonymi, gdyż jest ono sakramentem. Nauczanie o sakramentalności małżeństwa oparte jest o Pismo Święte, w szczególności o nauczanie św. Pawła Apostoła w Liście do Efezjan $(5,22-32)^{23}$. W małżeństwie ochrzczonych istnieje jedność elementów naturalnego i nadprzyrodzonego. Dzięki swej preegzystencji naturalnej małżeństwo ochrzczonych jest tą rzeczywistością sakramentalną, w której spotykają się ze sobą i przenikają natura i nadprzyrodzonośćc4. Sakramentalne przymierze małżeńskie charakteryzuje się trwałością i nierozerwalnością. Przymierze

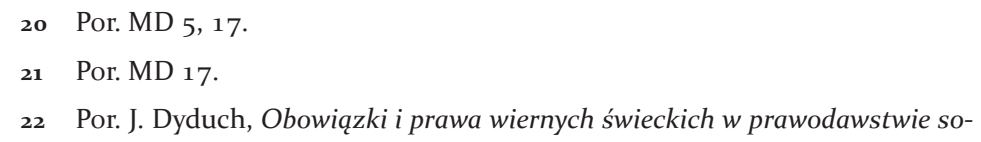
borowym, Kraków 1985, s. 223.

23 Por. M. Żurowski, Kanoniczne prawo matżeńskie Kościoła katolickiego, Katowice 1987 , s. 31-36.

24 Por. E. Corecco, Fundamentalne znaczenie sakramentu małżeństwa dla struktury Kościoła, „Communio. Międzynarodowy Przegląd Teologiczny” 1 (1981) nr 5 , s. 49 . 
małżeńskie ochrzczonych należy jednocześnie do porządku stworzenia i odkupienia ${ }^{25}$.

Sakramentalna wspólnota małżeńska jest podstawą rodziny chrześcijańskiej. Powinna ona być szkołą wiary i świętości oraz stanowić podstawową komórkę Kościoła i społeczności świeckiej. Jest nazywana także „Kościołem domowym”. Do jej podstawowych zadań należy służba życiu i jego ochrona, a także posłannictwo ewangelizacyjne i uświęcające ${ }^{26}$. W rodzinie chrześcijańskiej realizuje się macierzyństwo kobiety. Realizuje się ono również w innych rodzinach, a także poza nimi. Sprawa ta wymaga odrębnego omówienia.

Macierzyństwo jest nastawione na nową osobę, na dziecko: „Wzajemny dar osoby w małżeństwie otwiera się na dar nowego życia, nowego człowieka, który również jest osobą na podobieństwo swoich rodziców. Macierzyństwo zawiera w sobie od samego początku szczególne otwarcie na nową osobę: ono właśnie jest udziałem kobiety" ${ }^{27}$. Kobieta w poczęciu i urodzeniu dziecka odnajduje siebie przez bezinteresowny dar z siebie samej. To Stwórca obdarowuje obojga rodziców dzieckiem, bowiem małżeństwa uczestniczą w stwórczej mocy Boga ${ }^{28}$. Ludzkie rodzicielstwo jest wspólne mężczyźnie i kobiecie, oni mogą powiedzieć „to jest nasze dziecko”. Jednak w tym wspólnym rodzicielstwie kobieta ma udział szczególny: „Chociaż więc oboje razem są rodzicami swojego dziecka, to macierzyństwo kobiety stanowi szczególną część tego wspólnego rodzicielstwa,

25 D. O’Callaghan, W sprawie sakramentalności małżeństwa, „Concilium. Międzynarodowy Przegląd Teologiczny” 1-5 (1970), s. 346-347.

26 Por. J. Dyduch, Obowiązki i prawa..., dz. cyt., s. 235-242.

27 MD 18.

28 Por. MD 18. 
jego pełniej angażujący wymiar. Rodzicielstwo - chociaż należy do obojga - urzeczywistnia się o wiele bardziej w kobiecie, zwłaszcza w okresie prenatalnym" ${ }^{29}$. Rodzicielstwo realizuje się w dalszych etapach życia nowo narodzonego dziecka. Jego wychowywanie winno zawierać wkład zarówno macierzyński, jak i ojcowski, z tym że wkład macierzyński jest decydujący dla kształtowania nowej osobowości ludzkiejº ${ }^{30}$

Innym podstawowym wymiarem powołania kobiety jest dziewictwo dla królestwa niebieskiego. Chodzi tu o bezżenność dobrowolną, wybraną ze względu na królestwo niebieskie, czyli ze względu na eschatologiczne powołanie człowieka do zjednoczenia z Bogiem. Taka bezżenność - dziewictwo jest nie tylko owocem dobrowolnego wyboru, ale także szczególnej łaski Boga, który daną osobę wzywa do bezżenności. Ewangelia ukazuje wartość dziewictwa - zarówno dla mężczyzny, jak i dla kobiety. Jest to droga radykalizmu ewangelicznego, na którą od początku chrześcijaństwa wchodzą mężczyźni i kobiety ${ }^{31}$. Wybór takiej drogi jest także spełnieniem kobiecej osobowości: „W dobrowolnie wybranym dziewictwie kobieta potwierdza siebie jako osobę, czyli tę istotę, której Stwórca od początku chciał dla niej samej. Równocześnie zaś realizuje osobową wartość swej kobiecości, stając się bezinteresownym darem dla Boga, który objawił siebie w Chrystusie, darem dla Chrystusa, Odkupiciela człowieka i Oblubieńca dusz, darem oblubieńczym" ${ }^{2}$. W ewangelicznym ideale dziewictwa urzeczywistnia się zarówno godność, jak i powołanie kobiety w sposób szczególny, gdyż „[...] dziewictwo nie ogranicza się

\footnotetext{
29 MD 18.

30 Por. MD 18.

31 Por. MD 20.

32 MD 20.
} 
do samego «nie», natomiast zawiera głębokie «tak» w porządku oblubieńczym: oddanie siebie z miłości w sposób zupełny i niepodzielny"33.

Dziewictwo w znaczeniu ewangelicznym skutkuje wyrzeczeniem się małżeństwa i macierzyństwa fizycznego. Jednak pozwala doświadczać macierzyństwa $\mathrm{w}$ innym znaczeniu: macierzyństwa według Ducha. To duchowe macierzyństwo jawi się różnorako: „W życiu kobiet konsekrowanych, które żyją - na przykład - wedle charyzmatu i reguł różnych instytutów o charakterze apostolskim, może się ono wyrażać jako troska o ludzi, zwłaszcza najbardziej potrzebujących: o chorych, niepełnosprawnych, opuszczonych, sieroty, starców, dzieci i młodzież, więźniów i, ogólnie biorąc, ludzi z marginesu" ${ }^{34}$. Miłość oblubieńcza, na której bazuje macierzyństwo duchowe, otwarta jest na wszystkich ludzi, których ogarnia miłość Chrystusa - Oblubieńca. Miłość do Chrystusa Oblubieńca wzywającego: „Wszystko, co uczyniliście jednemu z tych [...], Mnieście uczynili” (Mt 25, 40) jest źródłem i celem działań wypływających z macierzyństwa duchowego ${ }^{35}$.

\section{Uczestnictwo kobiet w kapłaństwie wspólnym}

Wszyscy ochrzczeni, zarówno mężczyźni, jak i kobiety, uczestniczą w kapłaństwie wspólnym Jezusa Chrystusa, zwanym inaczej kapłaństwem powszechnym czy chrzcielnym. Naucza Sobór Watykański II: „Ochrzczeni bowiem stanowią przez odrodzenie i namaszczenie Duchem Świętym dom duchowy i święte kapłaństwo, aby przez wszystkie uczynki właściwe chrześcijaninowi składać

\footnotetext{
$33 \mathrm{MD} 2 \mathrm{O}$.

$34 \mathrm{MD} 21$.

35 Por. MD 21.
} 
duchowe ofiary i głosić moc tego, który wezwał ich z ciemności do przedziwnego swego światła" ${ }^{6}$. W ten sposób Sobór przypomniał prawdę o kapłaństwie wiernych, która była żywa w pierwotnym Kościele. Jest to prawda mobilizująca i zobowiązująca wiernych do prowadzenia życia chrześcijańskiego przez składanie duchowych ofiar i świadectwa dawanego Chrystusowi.

Sobór Watykański II naucza dalej: „Kapłaństwo zaś wspólne wiernych i kapłaństwo służebne, czyli hierarchiczne, chociaż różnią się istotą, a nie tylko stopniem, są sobie jednak wzajemnie przyporządkowane, jedno i drugie bowiem we właściwy sobie sposób uczestniczy w jednym kapłaństwie Chrystusa" ${ }^{37}$. Tak więc kapłaństwo wspólne, jak i kapłaństwo hierarchiczne, czyli służebne, mają swoje źródło w jedynym kapłaństwie Jezusa Chrystusa. Są to dwie rzeczywistości różne, ale nie przeciwstawne, między którymi zachodzi bardzo ścisła łączność. Zarówno kapłaństwo wspólne, jak i kapłaństwo służebne są obrazem doskonałej harmonii Trójcy Świętej, dlatego między jednym a drugim istnieje doskonała jedność, jedno zakłada i uzupełnia drugie ${ }^{38}$.

W kapłaństwie hierarchicznym, zgodnie z Ewangelią i Tradycją Kościoła, mogą uczestniczyć tylko mężczyźni. Wobec wzmożonych ataków (nie tylko dyskusji) na tę prawdę w drugiej połowie XX wieku zaistniała potrzeba zabrania przez Urząd Nauczycielski Kościoła głosu w tej sprawie. Przywołamy niektóre wypowiedzi. Deklaracja w sprawie dopuszczenia kobiet do kapłaństwa urzędowego po przeprowadzeniu argumentacji teologicznej i historycznej stwierdza, że Kościół nie ma prawa dopuszczania kobiet do

\footnotetext{
36 KK 10.

37 KK 10.

38 Por. E. Corecco, La „sacra potestas” e i laici, „Studi Parmensi” 28 (1980), s. $33-36$.
} 
święceń kapłańskich ${ }^{39}$. Odwołując się do Ewangelii, Jan Paweł II naucza: „Powołując samych mężczyzn na swych apostołów, Chrystus uczynił to w sposób całkowicie wolny i suwerenny" ${ }^{40}$. Błędne poglądy i domaganie się przez niektóre środowiska udzielania święceń kobietom, również w Kościele katolickim, skłoniły Jana Pawła II do wydania listu apostolskiego o udzielaniu święceń kapłańskich wyłącznie mężczyznom ${ }^{41}$. Stwierdza on: „Aby zatem usunąć wszelką wątpliwość w sprawie tak wielkiej wagi, która dotyczy samego Boskiego ustanowienia Kościoła, mocą mojego urzędu utwierdzania braci (por. Łk 22, 32) oświadczam, że Kościół nie ma żadnej władzy udzielania święceń kapłańskich kobietom oraz że orzeczenie to powinno być przez wszystkich wiernych Kościoła uznane za ostateczne"42. Papież określił, iż to orzeczenie, dotyczące wyłącznego udzielania święceń mężczyznom, jest ostateczne. Orzeczenie to jest nieomylne, jednak nie stanowi definicji dogmatycznej. Nie jest wszakże wykluczone, że w przyszłości stanie się ono definicją dogmatyczną ${ }^{43}$. Od czasu ogłoszenia przywołanego listu Ordinatio sacerdotalis nie można podejmować dyskusji na temat udzielania święceń kobietom, gdyż sprawa ta została definitywnie rozstrzygnięta. Wolno natomiast poszukiwać dodatkowych argumentów przemawiających za rozstrzygniętą tezą, nie zapominając

39 Kongregacja Doktryny Wiary, Deklaracja Inter insigniores, 15.10.1976, „Acta Apostolicae Sedis” [dalej: AAS] 69 (1977), s. 98-116.

$40 \mathrm{MD} 26$.

41 Jan Paweł II, list apost. Ordinatio sacerdotalis, 22.05.1994, Città del Vaticano 1994 .

42 Jan Paweł II, list apost. Ordinatio sacerdotalis, 4.

43 Por. Kongregacja Doktryny Wiary, Wyjaśnienie doktrynalne dotyczące końcowej części formuły Wyznania wiary, 29 VI 1998, „L'Osservatore Romano” wyd. pol. 19 (1998) nr 10, s. 18. 
o podstawowym argumencie, jakim jest wyraźna wola Jezusa Chrystusa. Dla zapobieżenia w praktyce udzielania święceń kobietom została wprowadzona surowa kara kanoniczna, grożąca ekskomuniką latae sententiae zarezerwowaną dla Stolicy Apostolskiej za usiłowanie ich udzielania, dotykająca zarówno tego, kto usiłuje ich udzielić, jak i kobietę, która usiłuje je przyjąćt4.

Mając na uwadze stanowisko Chrystusa i Kościoła o nieudzielaniu święceń kapłańskich kobietom, pytamy: czy to nie narusza godności kobiety i jej równości z mężczyzną? Wydaje się, że odpowiedź w dużej mierze znajduje się w powyżej przeprowadzonych rozważaniach o godności kobiety. Trzeba ją uzupełnić stwierdzeniem, że ta odmowa nie dotyczy porządku godności i równości, ale porządku zadań. Porządek ten ma to do siebie, że zakłada różnorodność funkcji. Tak więc istnieje ta sama godność osoby ludzkiej, mężczyzny i kobiety, także ich równość osobowa, której różnorodność w pełnionych funkcjach i zadaniach nie przeszkadza, a którą nawet zakłada. Stąd nieposiadanie przez kobiety święceń i niewykonywanie funkcji z nich wypływających nie narusza ich godności i równości z mężczyzną.

Chcąc docenić godność kobiety, Sobór Watykański II naucza: „Skoro zaś w naszych czasach kobiety biorą coraz żywszy udział w życiu społecznym, jest sprawą wielkiej wagi ich większe uczestnictwo także na różnych polach apostolskiej działalności Kościoła” ${ }^{4}$. W myśl tego postulatu dokumenty posoborowe przyznały kobietom możliwości różnorodnej działalności apostolskiej, a nawet duszpasterskiej w Kościele. Zagadnienie to wymaga odrębnego opracowania. Zajmiemy się jedynie ważną posługą kościelną,

44 Kongregacja Doktryny Wiary, Dekret, 30.05.2008, „Communicationes” 40 (2008) $\mathrm{nr} 1$, s. 87.

45 Sobór Watykański II, dekret Apostolicam actuositatem [dalej: DA], 9. 
dostępną również dla kobiet, jaką jest funkcja nadzwyczajnego szafarza komunii świętej.

Sprawę tę reguluje instrukcja Immensae caritatis wydana przez Kongregację Dyscypliny Sakramentów 29 stycznia 1973 roku$^{46}$. Przyznaje ona ordynariuszom miejsca upoważnienie do udzielania świeckim zezwolenia na rozdzielanie komunii świętej, na zanoszenie jej chorym do domów, również jako wiatyk. Takich zezwoleń ordynariusze miejsca mogą udzielać w poszczególnych przypadkach, na określony czas lub na stałe, wówczas gdy: a) nie ma kapłana, diakona lub akolity; b) wymienieni nie mogą udzielać komunii świętej z powodu wykonywania innej posługi duszpasterskiej, braku zdrowia lub starości; c) liczba wiernych przystępujących do komunii świętej jest tak wielka, że msza święta zbytnio by się przeciągała lub rozdzielanie komunii świętej poza mszą świętą trwałoby za długo. Ordynariusz miejsca może także upoważnić poszczególnych kapłanów do wyznaczenia osób świeckich, które w sytuacji prawdziwej konieczności udzielałyby komunii świętej w pojedynczych przypadkach ${ }^{47}$.

Wierny świecki wyznaczony na nadzwyczajnego szafarza komunii świętej winien być odpowiednio przygotowany, ma odznaczać się wzorowym życiem chrześcijańskim i głęboką czcią do Eucharystii. Przywołana instrukcja podaje następującą kolejność przy wyznaczaniu nadzwyczajnych szafarzy komunii świętej: lektor, alumn wyższego seminarium, zakonnik, zakonnica, katechista, wierny świecki: mężczyzna lub kobieta ${ }^{48}$. Instrukcja zezwala

46 Kongregacja Dyscypliny Sakramentów, Instrukcja Immensae caritatis, 29.01.1973, AAS 65 (1973), s. 264-271, tłum. pol. w: Posoborowe prawodawstwo kościelne, przeł. E. Sztafrowski, t. 6, z. 2, Warszawa 1975, s. 114-129.

47 Por. Kongregacja Dyscypliny Sakramentów, instr. Immensae caritatis, 1.

48 Por. Kongregacja Dyscypliny Sakramentów, instr. Immensae caritatis, 1. 
na zmianę tej kolejności, dlatego ordynariusz miejsca nie jest zobowiązany ściśle tej kolejności przestrzegać49. Postanowienie instrukcji potwierdza Kodeks prawa kanonicznego (KPK): „Tam, gdzie to doradza konieczność Kościoła, z braku szafarzy, także świeccy, chociażby nie byli lektorami lub akolitami, mogą wykonywać pewne obowiązki w ich zastępstwie, mianowicie: posługę słowa, przewodniczyć modlitwom liturgicznym, udzielać chrztu, a także rozdzielać komunię świętą, zgodnie z przepisami prawa" (kan. 230 § 3). Oto niektóre z tych przepisów: przywołana instrukcja Immensae caritatis, następnie instrukcja Inaestimabile donum $^{50}$, instrukcja Ecclesiae de mysterio ${ }^{51}$.

Prawodawstwo kościelne zezwala nadzwyczajnym szafarzom na wystawianie Najświętszego Sakramentu: „Szafarzem wystawienia Najświętszego Sakramentu i błogosławieństwa eucharystycznego jest kapłan lub diakon. W szczególnych okolicznościach tylko wystawienia i schowania, jednak bez błogosławieństwa, może dokonać akolita, szafarz nadzwyczajny komunii świętej lub ktoś inny wyznaczony przez ordynariusza miejsca, z zachowaniem przepisów wydanych przez biskupa diecezjalnego" (kan. 943 KPK). Te szczególne okoliczności to brak kapłana i diakona lub ich nieobecność z ważnego powodu. Ta funkcja, w określonych warunkach, jest dostępna także dla kobiet.

49 Por. E. Sztafrowski, Tajemnica Eucharystii w praktyce życia chrześcijańskiego, [w:] Sakramenty wtajemniczenia chrześcijańskiego, red. J. Kudasiewicz, Warszawa 1981, s. 443.

50 Kongregacja Sakramentów i Kultu Bożego, Instrukcja Inaestimabile donum, 3.04.1980, AAS 72 (1980), s. 331-343, tłum pol. w: Posoborowe prawodawstwo kościelne, przeł. E. Sztafrowski, t. 12, z. 1, Warszawa 1983, s. 333-350.

51 Instrukcja międzydykasterialna Ecclesiae de mysterio, 15.07.1997, „L'Osservatore Romano", wyd pol. 19 (1998) nr 12, s. 38, art. 8. 


\section{Zakończenie}

Kobiety tak jak mężczyźni są obdarzone godnością osoby ludzkiej jako istoty rozumne i wolne, stworzone na obraz i podobieństwo Boże. Kobieta w godności osoby ludzkiej jest w pełnej równości z mężczyzną. Ma ona dodatkowe atrybuty godności, a są nimi macierzyństwo fizyczne i duchowe. Uczestnicząc w kapłaństwie wspólnym Jezusa Chrystusa, z Jego woli nie uczestniczy w kapłaństwie służebnym. Nie powoduje to jednak osłabienia czy poniżenia jej godności.

SUMMARY

\section{The dignity of a woman in the Church}

In the face of the feminists' movements that in the essence humiliate the dignity of a woman, the genuine dignity of a woman must be shown. The dignity in question is based on the truth that woman is a rational being, equal to man in personal dignity, created by God in His own image. The additional attribute of a woman is the physical and spiritual motherhood. Of course, woman differs from man in the order of many things. The fact in question, as well as the lack of possibility for a woman to be a member of ministerial priesthood, neither disturbs nor diminishes the dignity of a woman.

Keywords: human person, dignity of a woman, ministerial priesthood, rational being

ks. Jan Dyduch, Godność kobiety w Kościele, [w:] Prawa dziecka: perspektywa Kościoła, red. ks. Piotr Kroczek, Kraków 2015, s. 47-62 (Annales Canonici Monographiae, 3). 